\title{
Molecular Detection of Selected Pathogens with Zoonotic Potential in Deer Keds (Lipoptena fortisetosa)
}

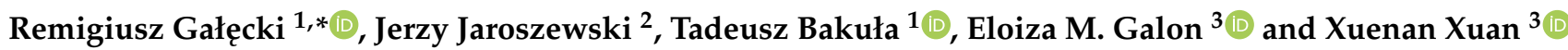 \\ 1 Department of Veterinary Prevention and Feed Hygiene, Faculty of Veterinary Medicine, University of \\ Warmia and Mazury in Olsztyn, 10-719 Olsztyn, Poland; bakta@uwm.edu.pl \\ 2 Department of Pharmacology and Toxicology, Faculty of Veterinary Medicine, University of Warmia and \\ Mazury in Olsztyn, 10-719 Olsztyn, Poland; jerzyj@uwm.edu.pl \\ 3 National Research Center for Protozoan Diseases, Obihiro University of Agriculture and Veterinary Medicine, \\ Obihiro 080-8555, Japan; eloizagalon@gmail.com (E.M.G.); gen@obihiro.ac.jp (X.X.) \\ * Correspondence: remigiusz.galecki@uwm.edu.pl
}

check for updates

Citation: Gałęcki, R.; Jaroszewski, J.;

Bakuła, T.; Galon, E.M.; Xuan, X.

Molecular Detection of Selected Pathogens with Zoonotic Potential in Deer Keds (Lipoptena fortisetosa). Pathogens 2021, 10, 324. https:// doi.org/10.3390/pathogens10030324

Academic Editor: Alfonso Zecconi

Received: 31 January 2021

Accepted: 7 March 2021

Published: 10 March 2021

Publisher's Note: MDPI stays neutral with regard to jurisdictional claims in published maps and institutional affiliations.

Copyright: (c) 2021 by the authors. Licensee MDPI, Basel, Switzerland. This article is an open access article distributed under the terms and conditions of the Creative Commons Attribution (CC BY) license (https:/ / creativecommons.org/licenses/by/ $4.0 /)$.

\begin{abstract}
Deer keds are obligatory hematophagous ectoparasites of birds and mammals. Cervids serve as specific hosts for these insects. However, ked infestations have been observed in non-specific hosts, including humans, companion animals, and livestock. Lipoptena fortisetosa is a weakly studied ectoparasite, but there is evidence to indicate that it continues to spread across Europe. The existing knowledge on deer keds' impact on wildlife is superficial, and their veterinary importance is enigmatic. Lipoptena fortisetosa is a species with vectorial capacity, but potential pathogen transmission has not been assessed. The objective of this study was to evaluate the prevalence of selected pathogens in L. fortisetosa collected from cervids and host-seeking individuals in the environment. Out of 500 acquired samples, 307 (61.4\%) had genetic material from at least one tested pathogen. Our research suggests that $L$. fortisetosa may be a potential vector of several pathogens, including A. phagocytophilum, Babesia spp., Bartonella spp., Borellia spp., Coxiella-like endosymbionts, Francisiella tularensis, Mycoplasma spp., Rickettsia spp., and Theileria spp.; however, further, more extensive investigations are required to confirm this. The results of the study indicate that keds can be used as biological markers for investigating the prevalence of vector-borne diseases in the population of free-ranging cervids.
\end{abstract}

Keywords: deer keds; ectoparasite; Hippoboscidae; louse flies; PCR; vector; infectious diseases; vector-borne diseases

\section{Introduction}

The role of vectors in the transmission of infectious diseases has been researched extensively in recent years. The main arthropods with vector capacity are ticks, mosquitos, black flies, fleas and lice. Many indigenous insects with vector capacity have not been thoroughly investigated in Europe [1-3]. One of the most underestimated ectoparasites is the deer ked.

Deer keds (syn. louse flies) of the genus Lipoptena (family Hippoboscidae) are potential vectors of infectious diseases that have not been thoroughly studied to date [4]. Special attention should be paid to Lipoptena fortisetosa, an invasive species that continues to spread across Europe. Lipoptena fortisetosa is a blood-feeding ectoparasite that specifically targets cervids, including the sika deer (Cerous nippon), Siberian roe deer (Capreolus pygargus), and roe deer (Capreolus capreolus). This parasite also uses the red deer (Cervus elaphus), fallow deer (Dama dama), and moose (Alces alces) [5]. Lipoptena fortisetosa originates from eastern Siberia and the Far East [6]. The species was first described by Maa in Japan [6]. In Poland, L. fortisetosa was first identified in the region of Lower Silesia in the late 1980s, and its presence was confirmed in the Tatra Mountains and in northern Poland in 2007-2012 [5,7-12]. This ectoparasite was also isolated in the region of Wielkopolska in 2017 [13]. Deer keds 
target forest animals during host-seeking flights [14]. The duration of the host-seeking period is determined by the local microclimate and the insect's phenology [14]. Louse flies shed wings when they find a definitive host. They are highly mobile on the host's skin [15]. Deer keds reproduce by adenotrophic viviparity. The prevalence of Lipoptena spp. infestations in specific hosts ranges from $64 \%$ to $78 \%$, depending on the species $[16,17]$. These ectoparasites were also identified in non-specific hosts. Lipoptena fortisetosa has been isolated from dogs [13]. Izdebska [18] confirmed the presence of Lipoptena spp. in bison (Bison bonasus). Deer keds were also found to attack cattle and horses $[19,20]$. Louse fly attacks and bites have also been reported in humans [21-23]. A single host can be infested by up to 16,000 insects [24]. Bites of the Lipoptena spp. may cause acute to chronic, eosinophilic to lymphocytic deer ked dermatitis [25]. Other infection symptoms include loss of hair, allergic rhinitis, conjunctivitis, or even anaphylactic shock [25-28].

Vectors are part of the One Health concept because they are responsible for the transmission of pathogens between wildlife, livestock, companion animals and humans [29,30]. Pathogens carried by arthropods cause vector-borne diseases. Vectors can carry viruses, bacteria, protozoa and helmints. Vector-borne viruses include, among others, the Chikungunya virus, bluetongue disease virus, dengue virus, Crimean-Congo hemorrhagic fever virus, West Nile virus, hantavirus, and Zika virus. The following bacteria are also transmitted by vectors: Anaplasma spp., Bacillus spp., Bartonella spp., Borellia spp., Brucella spp., Clostridium spp., Coxiella spp., Erysipelothrix spp., Francisella spp., Leptospira spp., Listeria spp., Mycoplasma spp., Pasteurella spp., Rickettsia spp., Salmonella spp., and Yersinia spp. Vectors also play a very important role in the life cycle of protozoa, including Babesia spp., Leishmania spp., Plasmodium spp., Theileria spp., and Trypanosoma spp. Similarly to other flies of the family Hippoboscidae [31], L. fortisetosa are potential vectors of infectious diseases [4,32]. DNA of Coxiella spp., Theileria luwenshuni, and T. ovis have been identified in L. fortisetosa in molecular analysis [33]. Lipoptena fortisetosa can also act as a vector for Trypanosoma spp. [34]. Trypanosome DNA was detected in $20 \%$ of L. cervi and in $48.64 \%$ of L. fortisetosa [35]. Deer keds harbored genetic material of Anaplasma spp. and Rickettsia spp. [36,37]. In isolated cases, DNA of Borrelia spp. was identified in louse flies [38,39]. The prevalence of Bartonella spp., which is transmitted vertically in deer keds, has been widely researched [40-43]. These pathogens' DNA was found in up to $98 \%$ of louse flies [42,43].

The European population of L. fortisetosa continues to spread, and further research is needed to evaluate this ectoparasite's role in the spread of infectious diseases. The expansion of the insect's geographic range was confirmed by Italian and Estonian studies $[44,45]$. The existing research is largely based on single detections of the pathogen's genetic material. Most of the research was conducted in small and limited locations. Louse flies' impact on wildlife populations, livestock, companion animals and humans has not been fully elucidated. The identification of genetic material in these ectoparasites could contribute important information about pathogens.

The aim of this study was to identify pathogens with zoonotic potential (A. ovis, A. phagocytophilum, Babesia spp., Bartonella spp., Borellia spp., Coxiella spp., Francisiella tularensis, Mycoplasma spp., Rickettsia spp., and Theileria spp.) in L. fortisetosa infesting cervids and in host-seeking louse flies in the environment.

\section{Results}

Overall, 9 of the 10 analyzed pathogens' DNA was identified, including 5 in group $\mathrm{E}$ and 9 in group A. In group A, A. phagocytophilum was identified in $20(8 \%)$ samples, Babesia spp. -in 51 (20.4\%) samples, Bartonella spp. -in 158 (63.2\%) samples, Borrelia spp. —in $12(4.8 \%)$ samples, Coxiella spp. —in $12(4.8 \%)$ samples, Francisella spp. —in $7(2.8 \%)$ samples, Mycoplasma spp. —in 74 (29.6\%) samples, Rickettsia spp. -in 76 (30.4\%) samples, and Theileria spp. - in 49 (19.6\%) samples. In group E, Bartonella spp. was identified in $89(35.6 \%)$ samples, Coxiella spp. -in $3(1.2 \%)$ samples, Francisella tularensis, -in 2 (0.8\%) samples, Mycoplasma spp. —in 17 (6.8\%) samples, and Rickettsia spp. —in 30 (12\%) samples. Detailed data are presented in Table 1 . The representative sequences of selected 
pathogens were deposited in the GenBank database of the National Center for Biotechnology Information under the following accession numbers: A. phagocytophilum MW531454, MW531455; Babesia spp. MT350573, MW522567; Bartonella spp. MW531456, MW531457; Borrelia spp. MW531458, MW531459; Coxiella spp. MW526947, MW526948; Francisella spp. MW531460; Mycoplasma spp. MW547438, MW547439; Rickettsia spp. MW531461, MW531462; Theileria spp. MW531681, MW531682. The phylogenetic trees for the obtained sequences are presented in Figures 1-10.

Table 1. Prevalence of selected pathogens in Lipoptena fortisetosa with a division into voivodeships, groups, and sexes.

\begin{tabular}{|c|c|c|c|c|c|}
\hline \multirow[t]{2}{*}{ Species } & \multicolumn{2}{|c|}{ Group A } & \multicolumn{2}{|c|}{ Group E } & \multirow[t]{2}{*}{ Total n-500 } \\
\hline & & & & & \\
\hline \multirow{4}{*}{ Anaplasma ovis } & $\mathrm{M}$ & $\mathrm{F}$ & M & F & \\
\hline & n-99 & $n-151$ & $n-115$ & $n-135$ & \\
\hline & 0 & 0 & 0 & 0 & 0 \\
\hline & $(0 \%)$ & $(0 \%)$ & $(0 \%)$ & $(0 \%)$ & $(0 \%)$ \\
\hline Anaplasma & 6 & 14 & 0 & 0 & 20 \\
\hline phagocytophilum & $(6.0 \%)$ & $(9.3 \%)$ & $(0 \%)$ & $(0 \%)$ & $(4 \%)$ \\
\hline \multirow{2}{*}{ Babesia spp. } & 21 & 30 & 0 & 0 & 51 \\
\hline & $(21.21 \%)$ & $(19.86 \%)$ & $(0 \%)$ & $(0 \%)$ & $(10.2 \%)$ \\
\hline \multirow{2}{*}{ Bartonella spp. } & 64 & 94 & 37 & 52 & 247 \\
\hline & $(64.65 \%)$ & $(62.25 \%)$ & (32.17) & $(38.52 \%)$ & $(49.4 \%)$ \\
\hline \multirow{2}{*}{ Borrelia spp. } & 3 & 9 & 0 & 0 & 12 \\
\hline & $(3.03 \%)$ & $(6.6 \%)$ & $(0 \%)$ & $(0 \%)$ & $(24.30 \%)$ \\
\hline \multirow{2}{*}{ Coxiella spp. } & 3 & 9 & 1 & 2 & 15 \\
\hline & $(3.03 \%)$ & $(6.6 \%)$ & $(2.87 \%)$ & $(1.48 \%)$ & $(3 \%)$ \\
\hline \multirow{2}{*}{ Francisella spp. } & 2 & 5 & 0 & 2 & 9 \\
\hline & $(2.02 \%)$ & $(3.31 \%)$ & $(0 \%)$ & $(1.48 \%)$ & $(1.8 \%)$ \\
\hline \multirow{2}{*}{ Mycoplasma spp. } & 22 & 52 & 9 & 8 & 91 \\
\hline & $(22.22 \%)$ & $(34.44 \%)$ & $(7.82 \%)$ & $(5.93 \%)$ & $(18.2 \%)$ \\
\hline \multirow{2}{*}{ Rickettsia spp. } & 30 & 46 & 14 & 16 & 106 \\
\hline & $(30.30 \%)$ & $(30.46 \%)$ & $(12.17 \%)$ & $(3.2 \%)$ & $(21.2 \%)$ \\
\hline \multirow{2}{*}{ Theileria spp. } & 22 & 27 & 0 & 0 & 49 \\
\hline & $(22.22 \%)$ & $(17.88 \%)$ & $(0 \%)$ & $(0 \%)$ & $(9.8 \%)$ \\
\hline
\end{tabular}

Legend: A-Animals group; E-Environment group; M-male; F-female.

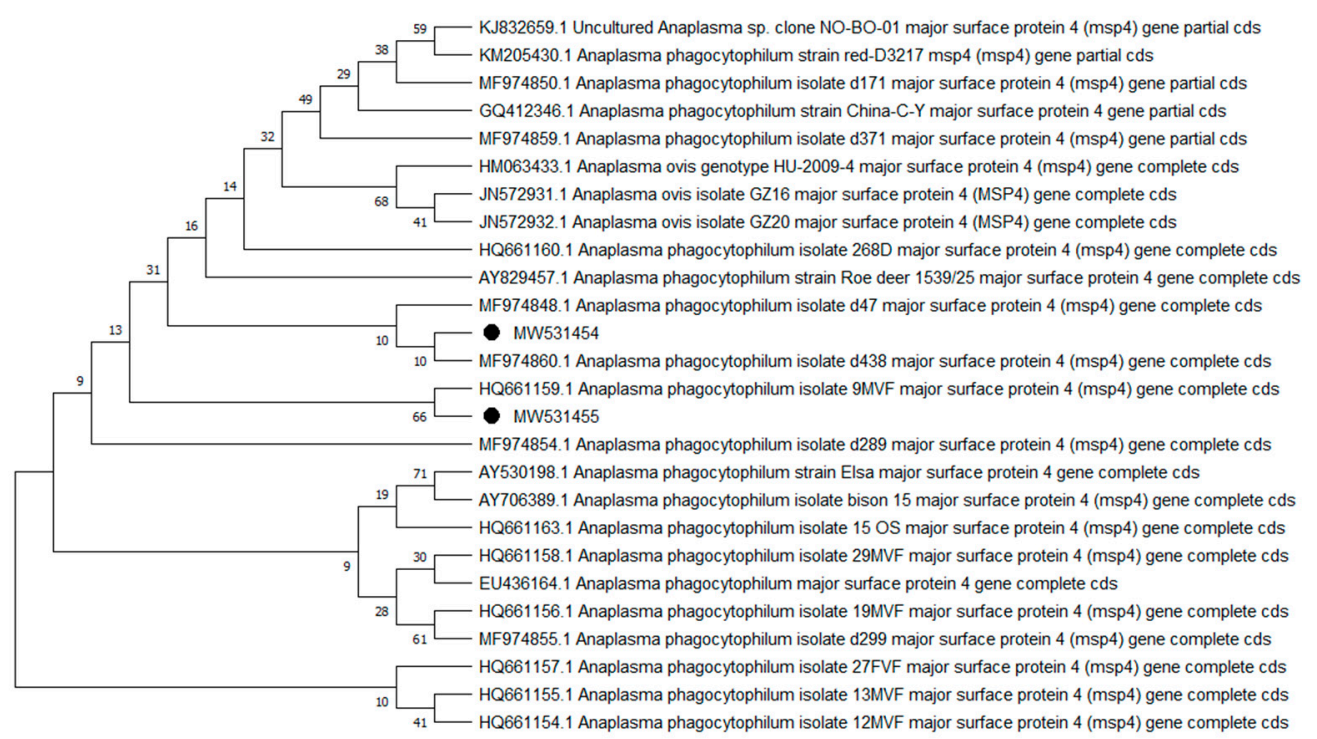

Figure 1. Phylogenetic topology for Neighbor Joining analysis of the MSP4 gene sequence of Anaplasma phagocytophilum. The unique haplotypes identified in this study are labeled with the corresponding sequence identification numbers and with dots. The reference sequences from GenBank are indicated in the tree. Bootstrap confidence values for branching reliability were calculated in 10,000 replicates. 


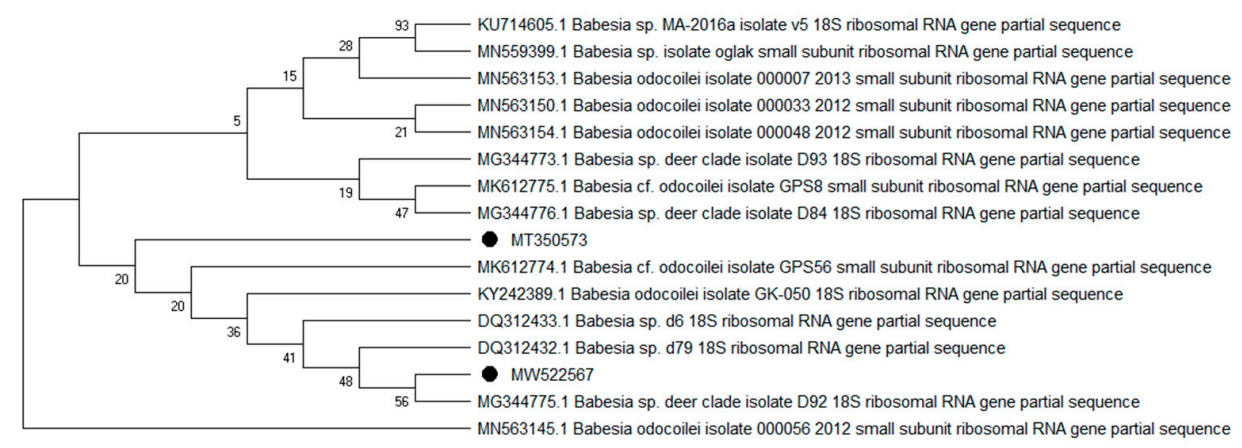

Figure 2. Phylogenetic topology for the Neighbor Joining analysis of the partial 18S rRNA gene sequence of Babesia spp. The unique haplotypes identified in this study are labeled with the corresponding sequence identification numbers and with dots. The reference sequences from GenBank are indicated in the tree. Bootstrap confidence values for branching reliability were calculated in 10,000 replicates.

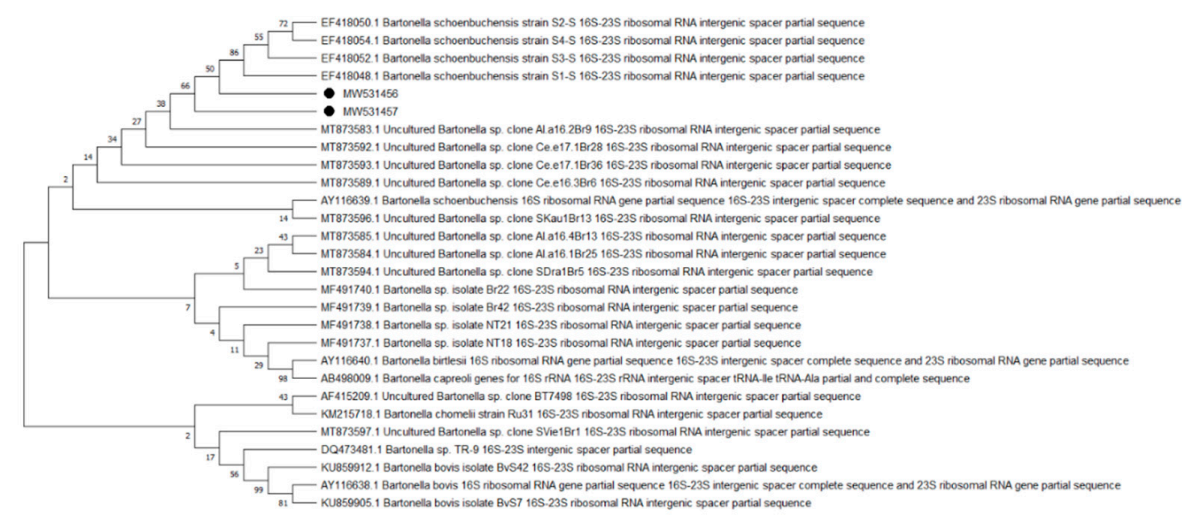

Figure 3. Phylogenetic topology for the Neighbor Joining analysis of the partial 16-23S gene sequence of Bartonella spp. The unique haplotypes identified in this study are labeled with the corresponding sequence identification numbers and with dots. The reference sequences from GenBank are indicated in the tree. Bootstrap confidence values for branching reliability were calculated in 10,000 replicates.

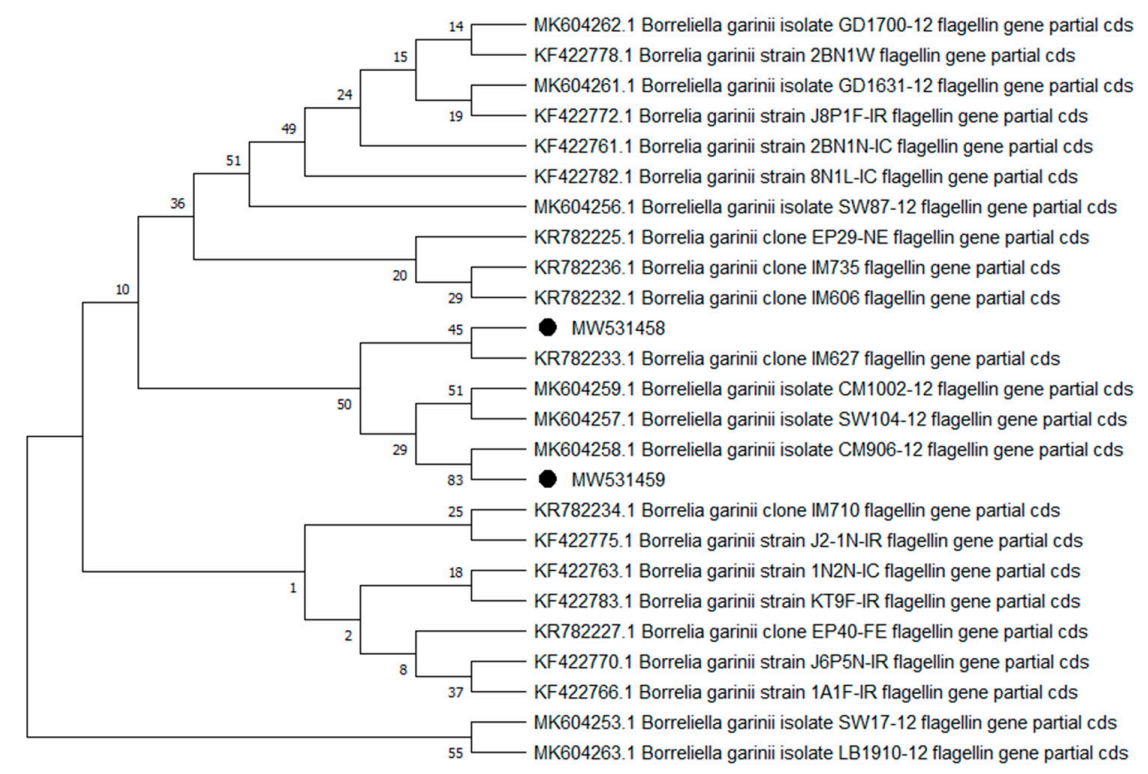

Figure 4. Phylogenetic topology for the Neighbor Joining analysis of the partial flagellin gene sequence of Borrelia spp. The unique haplotypes identified in this study are labeled with the corresponding sequence identification numbers and with dots. The reference sequences from GenBank are indicated in the tree. Bootstrap confidence values for branching reliability were calculated in 10,000 replicates. 


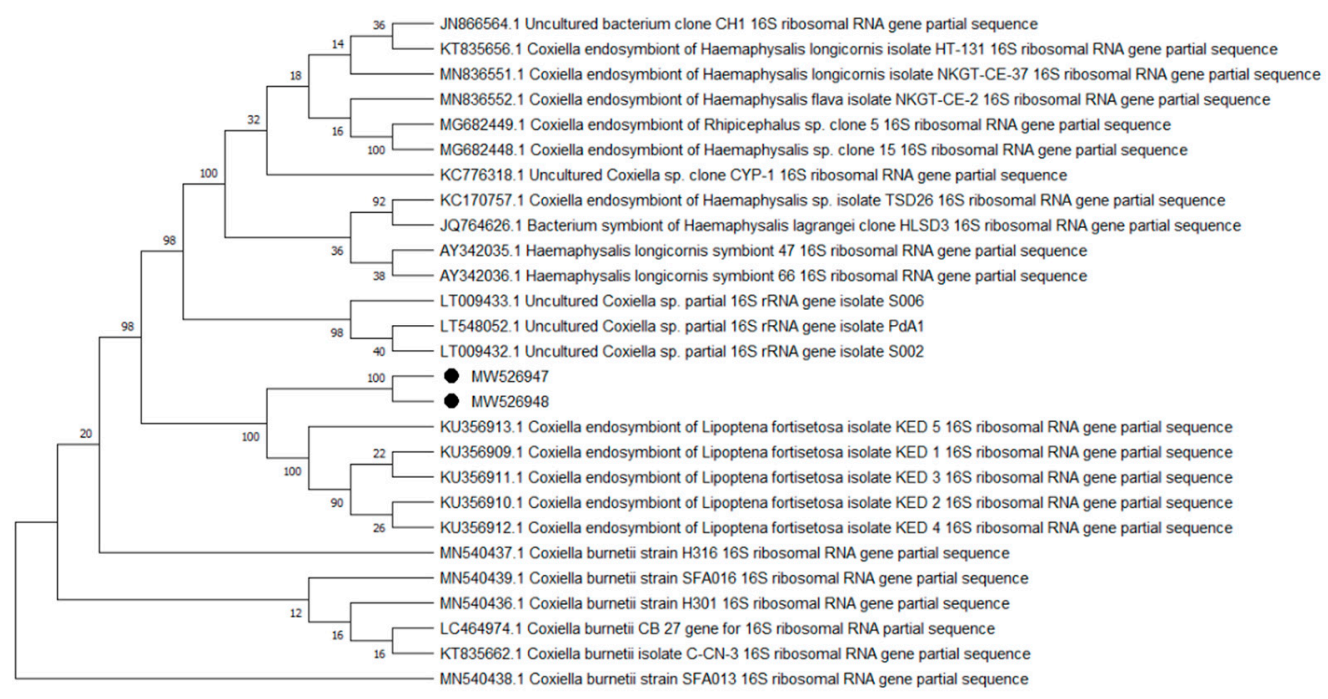

Figure 5. Phylogenetic topology for the Neighbor Joining analysis of the partial 16S rRNA gene sequence of Coxiella spp. The unique haplotypes identified in this study are labeled with the corresponding sequence identification numbers and with dots. The reference sequences from GenBank are indicated in the tree. Bootstrap confidence values for branching reliability were calculated in 10,000 replicates.

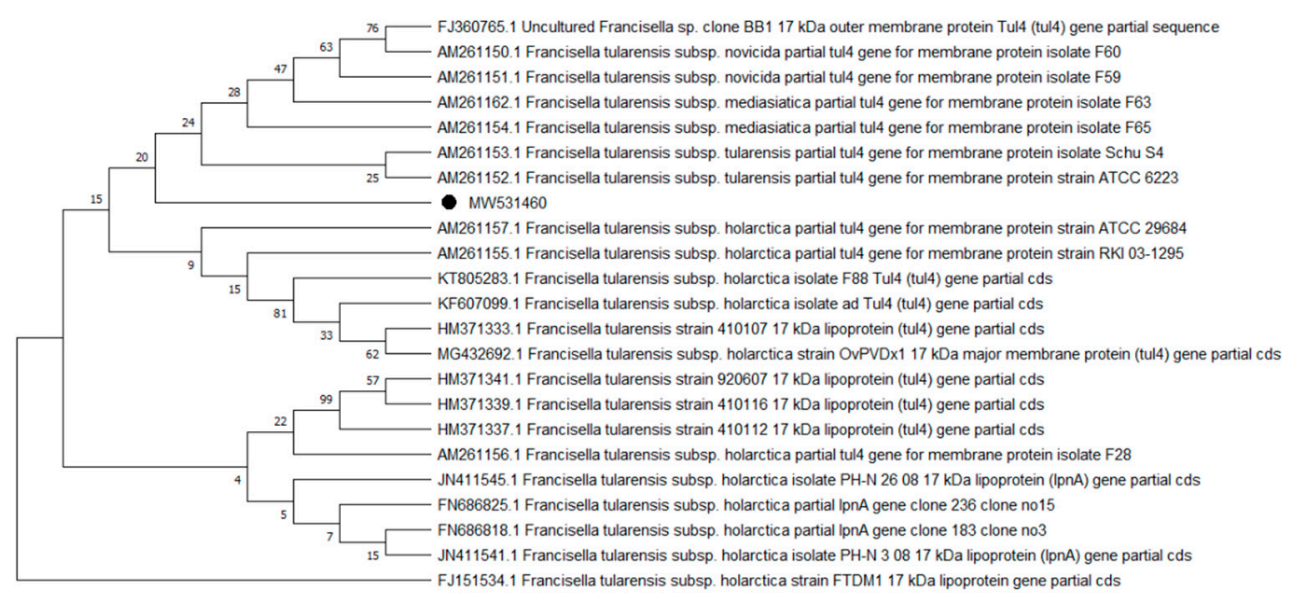

Figure 6. Phylogenetic topology for the Neighbor Joining analysis of the partial TUL4 gene sequence of Francisella spp. The unique haplotypes identified in this study are labeled with the corresponding sequence identification numbers and with dots. The reference sequences from GenBank are indicated in the tree. Bootstrap confidence values for branching reliability were calculated in 10,000 replicates.

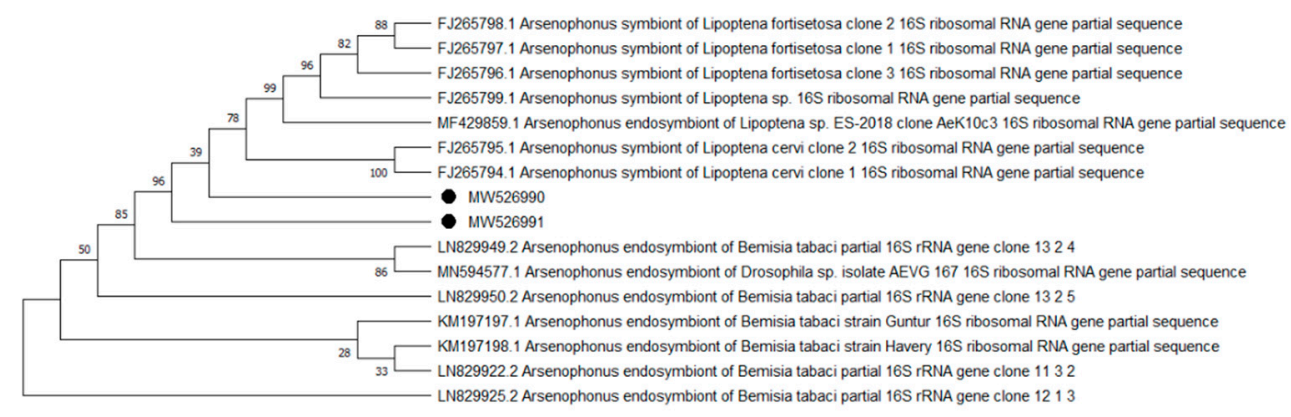

Figure 7. Phylogenetic topology for the Neighbor Joining analysis of the partial 16S rRNA gene sequence of Arsenophonus spp. The unique haplotypes identified in this study are labeled with the corresponding sequence identification numbers and with dots. The reference sequences from GenBank are indicated in the tree. Bootstrap confidence values for branching reliability were calculated in 10,000 replicates. The obtained sequences were acquired by cross-reaction. 


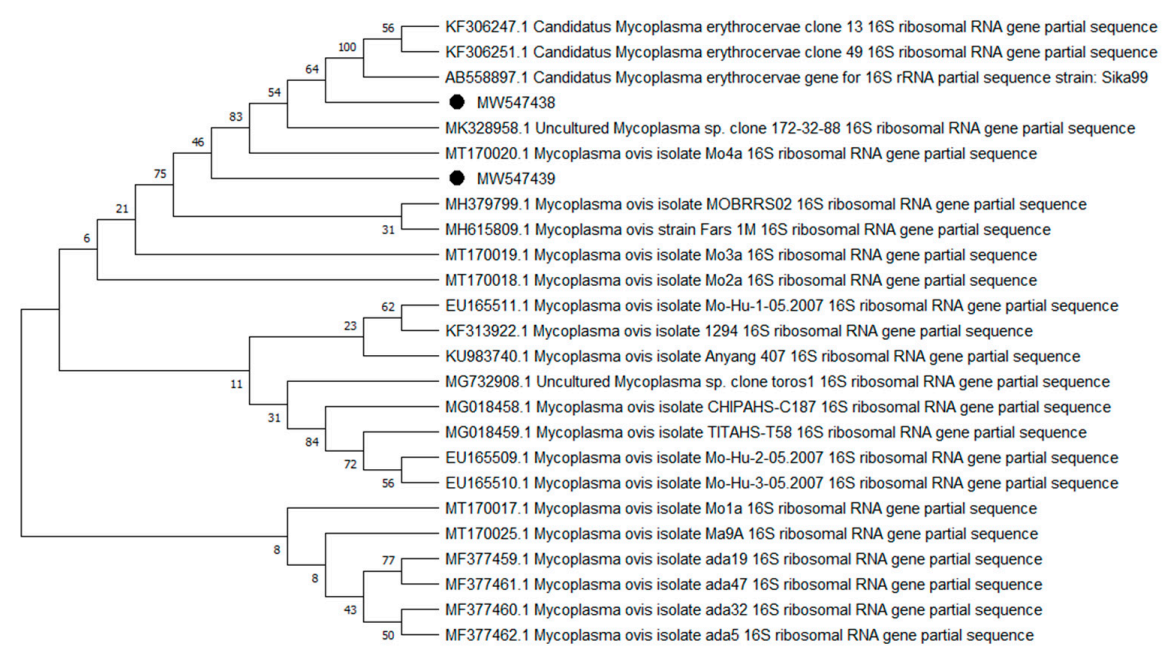

Figure 8. Phylogenetic topology for the Neighbor Joining analysis of the partial 16S rRNA gene sequence of Mycoplasma spp. The unique haplotypes identified in this study are labeled with the corresponding sequence identification numbers and with dots. The reference sequences from GenBank are indicated in the tree. Bootstrap confidence values for branching reliability were calculated in 10,000 replicates.

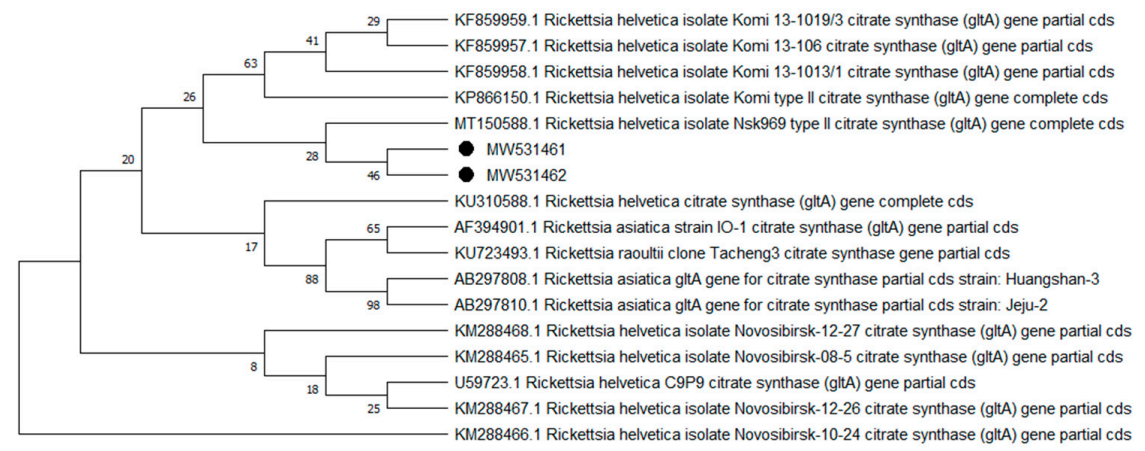

Figure 9. Phylogenetic topology for the Neighbor Joining analysis of the partial gltA gene sequence of Rickettsia spp. The unique haplotypes identified in this study are labeled with the corresponding sequence identification numbers and with dots. The reference sequences from GenBank are indicated in the tree. Bootstrap confidence values for branching reliability were calculated in 10,000 replicates.

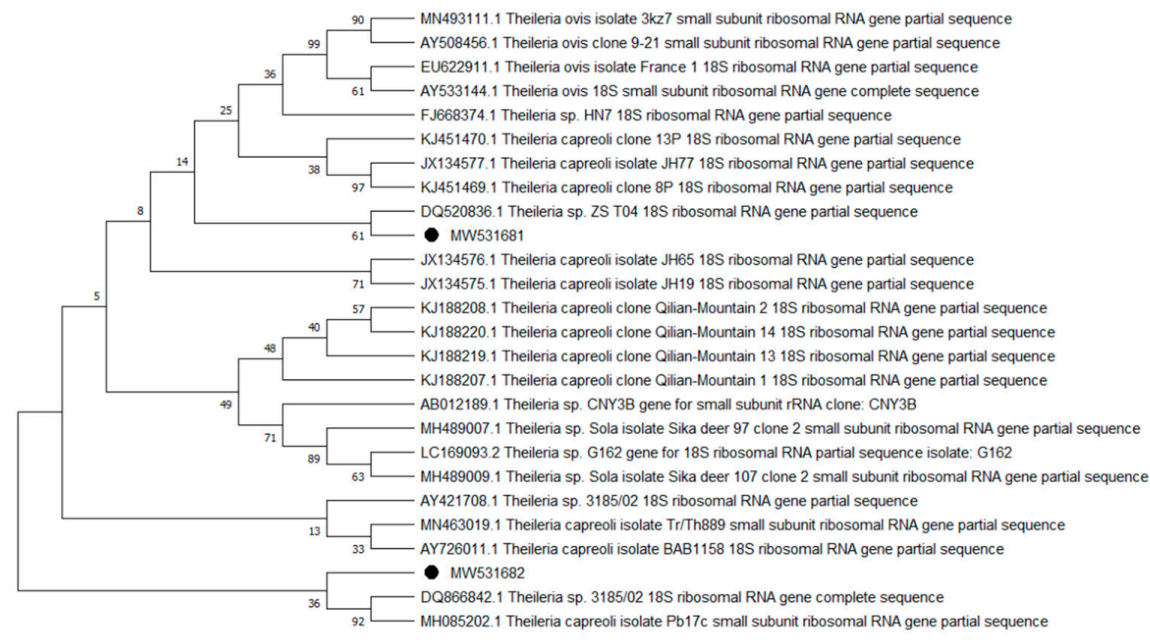

Figure 10. Phylogenetic topology for the Neighbor Joining analysis of the partial 18S rRNA gene sequence of Theileria spp. The unique haplotypes identified in this study are labeled with the corresponding sequence identification numbers and with dots. The reference sequences from GenBank are indicated in the tree. Bootstrap confidence values for branching reliability were calculated in 10,000 replicates. 
Anaplasma phagocytophilum sequences (MW531454, MW531455) were characterized by $99.76 \%$ similarity with sequences from Hungary (MF974860) and Slovakia (HQ661159). One sequence (MT350573) was identical with Babesia odocoilei from Norway (MK612774). One sequence (MW522567) was identical with Babesia spp. from the Czech Republic (MG344773). Bartonella schoenbuchensis sequences (MW531456, MW531457) were identical with sequences from France (AY116639) and Poland (EF418048, EF418052). Coxiella spp. sequences (MW531458, MW531459) were characterized by $97.63-97.64 \%$ similarity with sequences from South Korea (KU356909-KU356913). One sequence (MW531460) was identical with the Francisella tularensis subsp. holarctica sequence from Germany (EF418048, EF418052). The remaining sequences of Francisella spp. have been identified as Arsenophonus spp. One sequence (MW547438) was identical with the Candidatus Mycoplasma erythrocervae sequence from Japan (KF306251, KF306247, AB558897). Another Mycoplasma spp. sequence (MW547439) was identical with Mycoplasma ovis sequences, from Hungary (EU165509) and Turkey (MF377462). Sequences of Rickettsia spp. (MW531461, MW531462) were identical with Rickettsia helvetica sequences from Russia (KU310588) and France (U59723). One sequence (MW531681) was characterized by $99.73 \%$ similarity with the Theileria capreoli sequence from Turkey (MN463019). A second Theileria spp. sequence (MW531682) was identical with sequences from Turkey (MN463019) and Spain in red deer imported from Germany (AY421708).

Deer keds sampled from animals were significantly more likely to harbor pathogens than the insects from environmental samples. Detection of pathogens' genetic material was significantly higher in female than male flies. DNA of A. phagocyphilum was more frequently identified in females than males. Babesia spp. genetic material was significantly more prevalent in L. fortisetosa sampled in the Warmia-Masuria and Lubusz voivodeships. The prevalence of Bartonella spp., Coxiella spp., Mycoplasma spp., and Rickettsia spp. DNA was significantly higher in group A than in group E. Genetic material of Theileria spp. was less frequently detected in insects sampled in the Lubusz voivodeship. Detailed data are presented in Table 2.

Table 2. Logistic regression model presenting statistically significant relationships between the analyzed pathogens vs. the sex, group, and sampling site of deer keds.

\begin{tabular}{|c|c|c|c|c|c|c|c|}
\hline $\begin{array}{c}\text { Parasite Species } \\
\text { (Dependent Variables) }\end{array}$ & $\begin{array}{c}p \text {-Value } \\
\text { (for the Model) }\end{array}$ & $\begin{array}{r}\text { Inde } \\
\text { Va }\end{array}$ & $\begin{array}{l}\text { lent } \\
\text { es }\end{array}$ & $S E$ & $W$ & $p$-Value * & OR \\
\hline \multirow{2}{*}{ Total number } & \multirow{9}{*}{$<0.001$} & sex & $\begin{array}{c}\mathrm{M} \\
\mathrm{F}\end{array}$ & 0.32 & 4.06 & 0.044 & $\begin{array}{l}0.584 \\
1.476\end{array}$ \\
\hline & & group & $\begin{array}{l}\mathrm{A} \\
\mathrm{E}\end{array}$ & 0.22 & 92.32 & $<0.001$ & $\begin{array}{l}8.04 \\
0.12\end{array}$ \\
\hline Anaplasma phagocytophilum & & sex & $\begin{array}{c}\mathrm{M} \\
\mathrm{F}\end{array}$ & 0.56 & 2.85 & 0.03 & $\begin{array}{l}1.24 \\
0.88\end{array}$ \\
\hline Babesia spp. & & site & $\begin{array}{c}\text { WM } \\
\text { L }\end{array}$ & $\begin{array}{l}0.54 \\
0.55\end{array}$ & $\begin{array}{l}4.33 \\
3.67\end{array}$ & $\begin{array}{l}0.037 \\
0.045\end{array}$ & $\begin{array}{l}3.09 \\
2.85\end{array}$ \\
\hline Bartonella spp. & & group & $\begin{array}{l}\mathrm{A} \\
\mathrm{E}\end{array}$ & 0.20 & 26.04 & $<0.001$ & $\begin{array}{c}2.00 \\
0.803 \\
0.36\end{array}$ \\
\hline Coxiella spp. & & group & $\begin{array}{l}\mathrm{A} \\
\mathrm{E}\end{array}$ & 0.582 & 4.445 & 0.035 & $\begin{array}{l}3.410 \\
0.293\end{array}$ \\
\hline Mycoplasma spp. & & group & $\begin{array}{l}\text { A } \\
\text { E }\end{array}$ & 0.283 & 35.53 & $<0.001$ & $\begin{array}{l}5.40 \\
0.19\end{array}$ \\
\hline Rickettsia spp. & & group & $\begin{array}{l}A \\
E\end{array}$ & 0.226 & 16.559 & $<0.001$ & $\begin{array}{l}2.51 \\
0.40\end{array}$ \\
\hline Theileria spp. & & site & $\mathrm{L}$ & 0.653 & 6.483 & 0.011 & 0.19 \\
\hline
\end{tabular}

Legend: *—p-value < 0.05; SE—standard error; W-Wald coefficient; OR—odds ratio; M-male; F—female; A—animals group; Eenvironment group; WM-Warmia-Masuria; L-Lubusz. 
Significant relationships between the prevalence of the examined pathogens were observed. The values of Cramer's V were indicative of the absence of associations or weak associations. The relationships between the prevalence of the analyzed pathogens are presented in detail in Table 3.

Table 3. Associations between the prevalence of the analyzed pathogens in Lipoptena fortisetosa, based on the calculated values of Cramer's V.

\begin{tabular}{|c|c|c|c|c|c|c|c|c|c|}
\hline Species & $\begin{array}{c}\text { Anaplasma } \\
\text { phagocy- } \\
\text { tophilum }\end{array}$ & $\begin{array}{l}\text { Babesia } \\
\text { spp. }\end{array}$ & $\begin{array}{l}\text { Bartonella } \\
\text { spp. }\end{array}$ & $\begin{array}{c}\text { Borrelia } \\
\text { spp. }\end{array}$ & $\begin{array}{l}\text { Coxiella } \\
\text { spp. }\end{array}$ & $\begin{array}{c}\text { Francisella } \\
\text { tularensis }\end{array}$ & $\begin{array}{l}\text { Mycoplasma } \\
\text { spp. }\end{array}$ & $\begin{array}{l}\text { Rickettsia } \\
\text { spp. }\end{array}$ & $\begin{array}{l}\text { Theileria } \\
\text { spp. }\end{array}$ \\
\hline $\begin{array}{l}\text { Anaplasma } \\
\text { phagocy- } \\
\text { tophilum }\end{array}$ & - & $0.033^{b}$ & $0.013^{b}$ & $0.21^{*, a}$ & $0.20^{*}, \mathrm{a}$ & $0.057^{b}$ & $0.062^{b}$ & $0.035^{b}$ & $0.040^{\mathrm{b}}$ \\
\hline Babesia spp. & $0.079^{a}$ & - & $0.024^{\mathrm{b}}$ & $0.026^{b}$ & $0.029^{b}$ & $0.11^{\mathrm{b}}$ & $0.041^{b}$ & $0.011^{\mathrm{b}}$ & $0.050^{\mathrm{b}}$ \\
\hline $\begin{array}{l}\text { Bartonella } \\
\text { spp. }\end{array}$ & $0.026^{a}$ & $0.094^{*, \mathrm{a}}$ & - & $0.005^{b}$ & $0.016^{\mathrm{b}}$ & $0.037^{b}$ & $0.029^{b}$ & $0.009^{b}$ & $0.04^{\mathrm{b}}$ \\
\hline $\begin{array}{c}\text { Borrelia } \\
\text { spp. }\end{array}$ & $0.21^{*, a}$ & $0.077^{\mathrm{a}}$ & $0.032^{a}$ & - & $0.032^{b}$ & $0.043^{b}$ & $0.1^{b}$ & $0.027^{b}$ & $0.078^{b}$ \\
\hline $\begin{array}{l}\text { Coxiella } \\
\text { spp. }\end{array}$ & $0.16^{*, a}$ & $0.010^{\mathrm{a}}$ & $0.037^{a}$ & $0.043^{a}$ & - & $0.045^{b}$ & $0.073^{b}$ & $0.080^{\mathrm{b}}$ & $0.025^{b}$ \\
\hline $\begin{array}{l}\text { Francisella } \\
\text { spp. }\end{array}$ & $0.035^{\mathrm{a}}$ & $0.12 *, \mathrm{a}$ & $0.024^{a}$ & $0.025^{a}$ & $0.30^{\mathrm{a}}$ & - & $0.063^{b}$ & $0.059^{b}$ & $0.041^{b}$ \\
\hline $\begin{array}{l}\text { Mycoplasma } \\
\text { spp. }\end{array}$ & $0.01^{\mathrm{a}}$ & $0.13^{*, \mathrm{a}}$ & $0.028^{a}$ & $0.128^{*, \mathrm{a}}$ & $0.032^{a}$ & $0.13^{\mathrm{a}}$ & - & $0.028^{b}$ & $0.055^{b}$ \\
\hline $\begin{array}{l}\text { Rickettsia } \\
\text { spp. }\end{array}$ & $0.01^{\mathrm{a}}$ & $0.069^{a}$ & $0.077^{\mathrm{a}}$ & $0.0080^{a}$ & $0.11^{*, a}$ & $0.039^{a}$ & $0.050^{\mathrm{a}}$ & - & $0.046^{b}$ \\
\hline $\begin{array}{l}\text { Theileria } \\
\text { spp. }\end{array}$ & $0.08^{*, a}$ & $0.16^{*, a}$ & $0.11^{a}$ & $0.12 *, a$ & $0.012^{\mathrm{a}}$ & $0.008^{a}$ & $0.052^{a}$ & $0.090^{\mathrm{a}}$ & - \\
\hline
\end{tabular}

Legend: ${ }^{*}-\chi^{2} p$-value $<0.05{ }^{\text {a }}$ —Cramer's $\mathrm{V}$ for all samples; ${ }^{\mathrm{b}} \_$Cramer's $\mathrm{V}$ for animals group samples.

\section{Discussion}

The results of this study indicate that $L$. fortisetosa is ubiquitous in the analyzed voivodeships. In a previous study, this ectoparasite was identified only in isolated locations [5]. Deer keds could spread to new locations due to low level of host specificity as well as animal migrations. Lipoptena fortisetosa is an invasive species in Poland, but its population has been expanding steadily, which suggests that it has adapted well to the environmental conditions of Central Europe [14]. Louse flies infest hosts directly after pupation, and the emerged insects cover areas with a radius of $50 \mathrm{~m}$ [46]. Winged flies are responsible for the majority of non-specific host infestations, including in humans [23], companion animals [13], and livestock [19]. The host-seeking flights of L. fortisetosa may pose a threat for forest workers and hunters $[23,47]$. Hunters may become infested with Lipoptena spp. during the evisceration of wild animals. Hunting dogs may be attacked by these ectoparasites during tracking [13]. Cattle and horses grazing in the vicinity of forests also may be at risk of L. fortisetosa infestation $[19,20]$. People wearing dark clothing and animals with a dark fur coat are most susceptible to insect flights [48].

In this study, the prevalence and number of pathogens were lower in winged deer keds than in individuals sampled from cervids. Due to the fact that louse flies drop their wings upon attachment to the host, any subsequent switch in host is made more difficult [49]. However, Lipoptena spp. may switch hosts during the breeding season of cervids [50]. Infested mothers can also transmit these ectoparasites to their offspring [51]. In addition to insect bites, the infectious agent could also be transmitted when an insect is crushed on the skin [52]. Our results showed that Lipoptena fortisetosa carry DNA of pathogens, which might be collected through bloodmeal and transferred during the embryonic development of the larvae. The genetic material of Babesia spp., Borrelia spp., and Theileria spp. was detected only in deer keds that had direct contact with cervids. This is the first study to detect genetic material of Babesia spp. in deer keds. In addition, it is interesting to identify the DNA of Borrelia spp. in these ectoparasites in light of the fact that cervids are incompetent hosts for these bacteria [53]. The genetic material of Bartonella spp., Mycoplasma 
spp., and Rickettsia spp. was identified additionally in winged insects sampled from the environment. The presence of the wings means that these individuals had no previous contact with the host [54]. Some pathogens may be carried by vectors without direct contact with a host. This is generally the result of acquiring a blood meal by a female. Due to the characteristic development of the new generation, host seekers may still carry remnants of a previous blood meal.

Interestingly, the analyzed insects also harbored Coxiella spp. and Francisella tularensis, and the prevalence of these bacteria in deer keds has been poorly investigated to date. These bacterial species were identified in both insect groups; however, most of the obtained sequences were identified as endosymbionts. In addition, the present findings do not provide sufficient evidence to substantiate the above claim because the isolation kit used in this study is intended to detect trace amounts of DNA. Pupae developing in the forest understory could have been contaminated with environmental bacteria. Coxiella spp. and Francisella spp. colonize soil [55,56], where pupation occurs. Additionally, it is interesting to find the Candidatus Mycoplasma erythrocervae bacterium, which was most closely related to isolates from Japan [57]. Either the variance of this genetic material associated with the DNA fragment under test is low, or the pathogen has been introduced with sika deer (Cervus nippon). It is possible that with the introduction of this species to Poland, the pathogen expanded in the population of native cervids. The possible presence of another pathogen of Japanese origin (Bartonella spp.) was also suggested in other studies [43].

Our description of pathogens 'genetic material detection with molecular tests might be an important consideration in research on deer keds' role in the transmission of infectious diseases. This research allows for a preliminary determination of potential pathogens for which L. fortisetosa may serve as vector. However, the transmission of the infectious agents by L. fortisetosa should be evaluated with the use of Koch's postulates [58-60]. For example, the development of Babesia spp. and Theileria spp. in Lipoptena spp. seems doubtful because ticks are the only known definitive hosts for these protozoa [61]. However, further research is needed to confirm this assumption. Despite the above, deer keds may act as mechanic vectors for these pathogens [4,37]. Lipoptena cervi has been suggested to mechanically transmit A. phagocytophilum to cervids [37,62]. Hornok et al. [63] identified Theileria spp. in stable flies (Stomoxys calcitrans) and suggested that this ectoparasite may pose a risk of mechanical transmission of theilerioses. Therefore, the research should assess whether a similar phenomenon may occur in deer keds. Lipoptena fortisetosa may be the potential biological vector for Trypanosoma spp. [35]. Currently, Bartonella spp. is the most comprehensively studied pathogen carried by Lipoptena spp., which appears to pose the greatest risk in infestation with these ectoparasites [40-43].

In the present study, genetic material of pathogens was more frequently identified in female than male L. fortisetosa, which could be explained by the fact that, in some ectoparasite species, females ingest more food than males $[64,65]$. Female insects of the genus Lipoptena spp. suck blood to draw nutrients that are needed for embryogenesis and intrauterine feeding of larvae [66]. Moreover, the exposure to microorganisms that are sucked with blood by females might last longer in the next generation. The logistic regression model revealed differences in pathogen prevalence between groups, which could suggest that some pathogen DNA may still be present in host-seeking ectoparasites. This study explored the idea that several of the detected microorganisms' DNA might have been vertically transmitted. Some pathogens were also more prevalent in selected voivodeships. These differences can probably be attributed to variations in pathogen prevalence across cervid populations $[67,68]$. The calculated values of Cramer's V point to the absence of significant associations between the prevalence of the studied pathogens, which could suggest that other vectors play a role in the transmission of these infectious agents.

In the future, deer keds could be used as biological markers of vector-borne diseases in cervid populations, due to the biology and behavior of these ectoparasites as well as specific ectoparasite-host relationships [46]. The acquisition of biological material-in particular, blood-that is suitable for molecular analyses could be problematic if the appropriate 
transportation and analytical equipment and facilities are not available. Alternatively, Lipoptena spp. can be obtained from hosts that are more accessible during field studies. The present study demonstrated that DNA of the infectious agents might be identified in deer keds. In order to fully assess the potential of these ectoparasites as biological markers, it is necessary to compare the results of molecular analyses examining the blood samples with insects collected from the same animal.

Our studies showed that deer keds may harbor pathogenic microorganisms of significance; however, further investigation is needed to confirm whether intact and viable pathogens are indeed present, and if so, whether they can be transmitted by deer keds. Experiments performed on laboratory animals, which have not been performed to date, would elucidate the role of Lipoptena spp. in the eventual transmission of vector-borne diseases. Future research should focus on methods of controlling these ectoparasites and protecting humans and animals against their attacks. Greater attention should also be paid to L. fortisetosa in Central Europe, because its impact on indigenous cervid populations remains largely unknown.

\section{Materials and Methods}

\subsection{Sample Collection}

Deer keds were sampled in 2019 in five Polish voivodeships: Greater Poland, KuyaviaPomerania, Lubusz, Pomerania, and Warmia-Masuria. The location of these voivodeships on a map of Poland is presented in Figure 11. The collected specimens of L. fortisetosa were divided into two groups: Animals (A) - insects sampled from cervids, and Environment (E) - host-seeking insects sampled from the environment. A total of 500 L. fortisetosa individuals were sampled for the study. Group A was composed of 250 deer keds. Insects were collected from the bodies of dead or living cervids. One ectoparasite from each animal was randomly selected for analysis. Fifty individuals were acquired from each studied voivodeship. Group E consisted of 250 deer keds. Insects were collected in randomly selected Central European mixed forests. Up to 5 individuals of L. fortisetosa were acquired from each site. The investigator walked through the forest in the vicinity of wild animal habitats, wearing brown cotton clothing. Insects were captured after landing on the clothing and were immediately placed in test tubes. Fifty insects were obtained from each examined voivodeship. Group A and E ectoparasites were immersed in 70\% ethanol in test tubes.

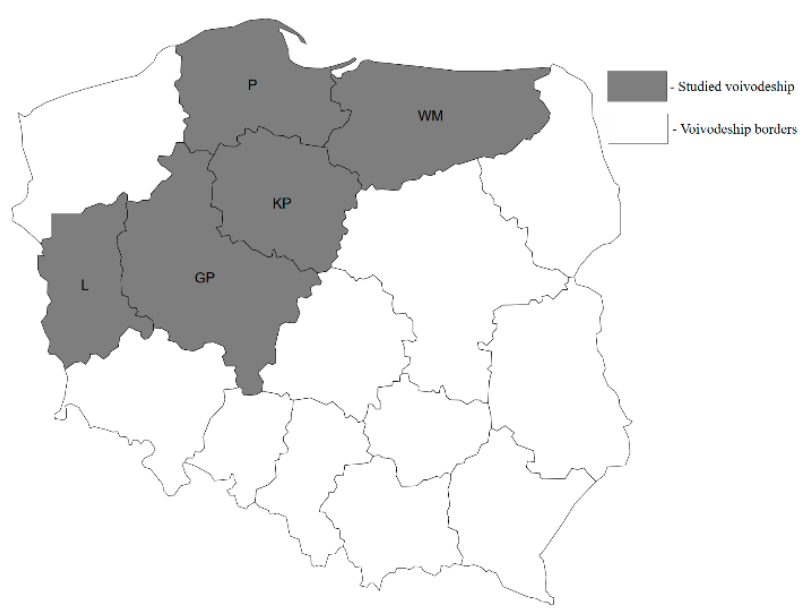

Figure 11. Map of Poland highlighting voivodships where Lipoptena fortisetosa samples were collected. Legend: GP—Greater Poland voivodeship; KP—Kuyavia-Pomerania voivodeship; L—Lubusz voivodeship; P-Pomerania voivodeship; WM-Warmia-Masuria voivodeship. 


\subsection{Species Identification}

The sampled insects were analyzed in the Biological Hazard Laboratory at the Faculty of Veterinary Medicine of the University of Warmia and Mazury in Olsztyn. The species and sex of $L$. fortisetosa were identified based on the number of erect hairs on the mesonotum, the length and structure of palpi, wing venation, and body dimensions [3,44]. Images were acquired under the Leica M165C stereoscopic microscope (Leica, Wetzlar, Germany) with the use of Leica Application Suite 4.4 software (Leica, Wetzlar, Germany). Samples containing different insect species were excluded from further analysis.

\subsection{DNA Extraction}

Lipoptena fortisetosa were removed from test tubes, dried at room temperature for 15 $\mathrm{min}$, and crushed individually with a sterile glass rod in sterile test tubes. Genomic DNA was extracted from each sample with the Sherlock AX universal kit (A\&A Biotechnology, Gdynia, Poland) according to the manufacturer's instructions. DNA was eluted in $40 \mu \mathrm{l}$ of TE buffer. The concentration of the final product was determined with the Nano Drop 2000 spectrophotometer (Thermo Fisher Scientific, Waltham, USA). The extracted DNA was stored at $-20^{\circ} \mathrm{C}$ until analysis.

\subsection{Selection of Pathogens for Analysis}

Based on a review of the literature [67-80], the following pathogens were selected and identified: Anaplasma ovis, A. phagocytophilum, Babesia spp., Bartonella spp., Borellia spp., Coxiella burnetii, Francisiella tularensis, Mycoplasma spp., Rickettsia spp., and Theileria spp.

\subsection{Polymerase Chain Reaction}

Primer sequences and PCR conditions are presented in Table 4. Every reaction was carried out in a final volume of $25 \mu \mathrm{L}$, containing $2.5 \mu \mathrm{L}$ of $10 \times$ Standard Taq Reaction Buffer (Biolabs, Boston, MA, USA, USA), $0.5 \mu \mathrm{L}$ of $10 \mathrm{mM}$ dNTPs (Biolabs, USA), $0.5 \mu \mathrm{L}$ of $10 \mu \mathrm{M}$ solution of each primer, $1 \mu \mathrm{L}$ of extracted DNA, $0.125 \mu \mathrm{L}$ of Taq DNA polymerase (Biolabs, USA), and $19.875 \mu \mathrm{L}$ of double-distilled water. The reaction was carried out in the Veriti Thermal Cycler (Applied Biosystems, Foster City, CA, USA). DNA was replaced with double-distilled water in the negative sample. The positive sample consisted of DNA samples of each analyzed pathogen and L. fortisetosa collected in a previous study. PCR products were electrophoresed on 1.5-2.5\% agarose gel using a 100 bp DNA ladder as a molecular-weight size marker, stained with ethidium bromide, and viewed under a UV transilluminator. The two strongest expressed bands in each studied pathogen were sequenced. All PCR products that were DNA positive for Francisella spp. were validated using sequencing. 
Table 4. Primers and PCR conditions.

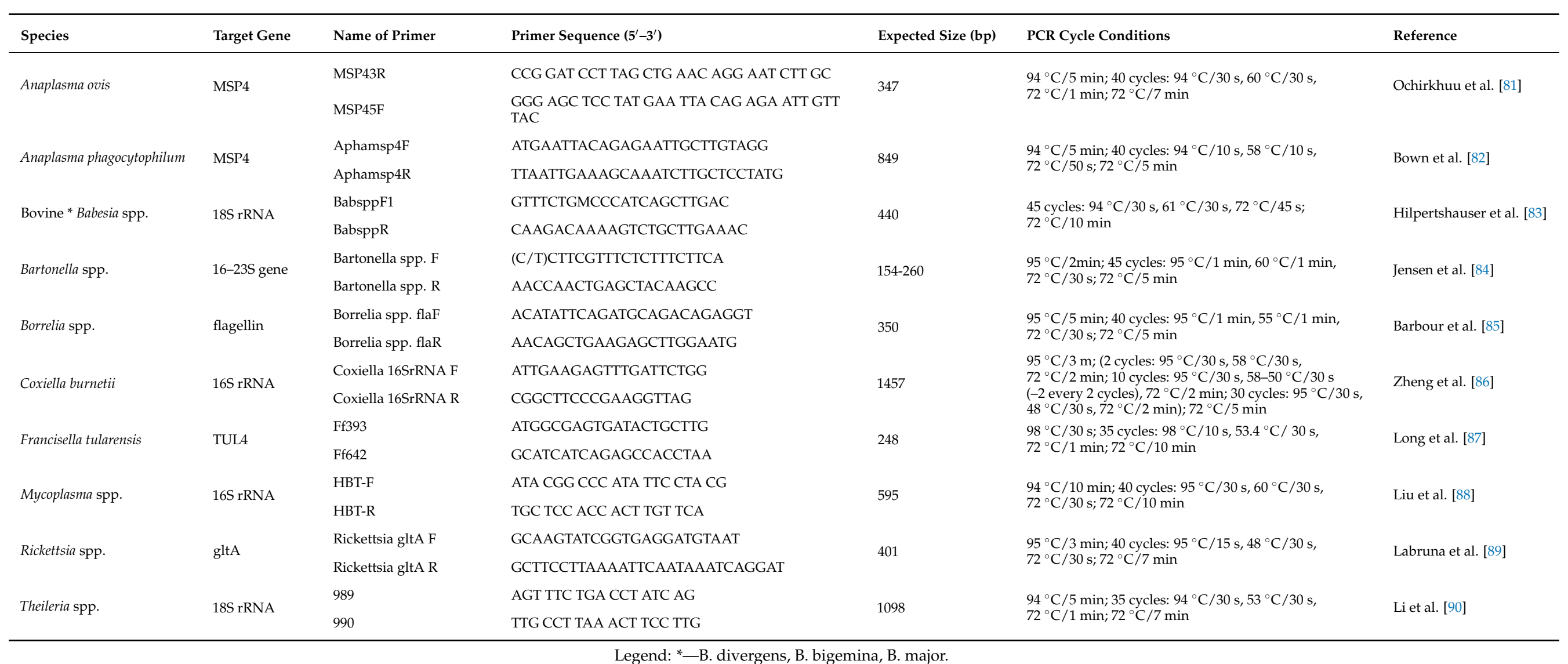




\subsection{Sequencing}

DNA samples were purified by ethanol precipitation. Cycle-sequencing reactions were carried out with the use of the described primers, BigDye Terminator Cycle Sequencing Kit (Applied Biosystems, Foster City, CA, USA), and the ABI PRISM 3100 Genetic Analyzer (Applied Biosystems, Foster City, CA, USA). The obtained nucleotide sequences were edited in the BioEdit program [91] and compared with GenBank data in the BLAST-NCBI program. A phylogenetic analysis of the obtained sequences and the corresponding GenBank sequences was conducted by the Neighbor Joining estimation in MEGA 10.1.17 [92]. Bootstrap confidence values for estimating branching reliability were calculated in 10,000 replicates.

\subsection{Statistical Analysis}

The significance of possible relationships between the presence of pathogens and sample characteristics was determined in a logistic regression model, where the dependent variable was the dichotomous variable (absence (0)/presence (1) of the analyzed pathogen), whereas the insects' sex (male/female), group (A or E), and site (examined voivodeships) were the independent variables. The associations between the prevalence of the analyzed pathogens were examined by calculating Cramer's V, where values close to 0 denoted weak associations and values approximating $+1 /-1$ denoted stronger associations. Data were processed statistically in the Statistica 13.3 program (TIBCO Software Inc., Palo Alto, Santa Clara, CA, USA).

\section{Conclusions}

The analyzed deer ked samples, obtained from animals and the environment, harbored the genetic material of A. phagocytophilum, Babesia spp., Bartonella spp., Borellia spp., Coxiellalike endosymbionts, Francisiella tularensis, Mycoplasma spp., Rickettsia spp., and Theileria spp. Deer keds may be used as biological markers for identifying pathogens in cervid populations, but further research is needed to confirm this assumption. Future research might reveal the competency of the L. fortisetosa as a biological or mechanical vector. The role of $L$. fortisetosa as a vector of pathogens requires further, more extensive investigations due to their new colonization sites and attacks on humans and animals. These are important considerations that require further attention.

Author Contributions: Conceptualization, R.G.; methodology, R.G.; software, R.G.; validation, R.G.; formal analysis, R.G. and E.M.G.; investigation, R.G.; resources, R.G.; data curation, R.G.; writingoriginal draft preparation, R.G.; writing-review and editing, R.G.; visualization, R.G.; supervision, J.J., X.X. and T.B.; project administration, R.G.; funding acquisition, R.G., J.J., X.X and T.B. All authors have read and agreed to the published version of the manuscript.

Funding: The project was financially supported by the Minister of Science and Higher Education under the program entitled "Regional initiative of Excellence" for the years 2019-2022, Project No. 010/RID/2018/19, amount of funding PLN 12,000,000. The funders had no role in the study design, data collection and analysis, decision to publish, or preparation of the manuscript.

Institutional Review Board Statement: Not applicable.

Informed Consent Statement: Not applicable.

Data Availability Statement: The original contributions presented in the study are included in the article. Further inquiries can be directed to the corresponding author.

Acknowledgments: The authors would like to thank the "Healthy Animal—Safe Food" Scientific Consortium of the Leading National Research Center (KNOW) (grant No. 05-1/KNOW2/2015) for supporting cooperation between the Faculty of Veterinary Medicine of the University of Warmia and Mazury in Olsztyn and the National Research Center for Protozoan Diseases of the Obihiro University of Agriculture and Veterinary Medicine. The authors are also grateful to hunters and forestry employees for their assistance in collecting research samples.

Conflicts of Interest: The authors declare no conflict of interest. 


\section{References}

1. Bueno-Marí, R.; Jiménez-Peydró, R. Anopheles plumbeus Stephens, 1828: A neglected malaria vector in Europe. Malar. Rep. 2011, 1, e2. [CrossRef]

2. Baldacchino, F.; Desquesnes, M.; Mihok, S.; Foil, L.D.; Duvallet, G.; Jittapalapong, S. Tabanids: Neglected subjects of research, but important vectors of disease agents! Infect. Genet. Evol. 2014, 28, 596-615. [CrossRef]

3. Salvetti, M.; Bianchi, A.; Marangi, M.; Barlaam, A.; Giacomelli, S.; Bertoletti, I.; Roy, L.; Giangaspero, A. Deer keds on wild ungulates in northern Italy, with a taxonomic key for the identification of Lipoptena spp. of Europe. Med. Vet. Entomol. 2019, 34, 74-85. [CrossRef] [PubMed]

4. Bezerra-Santos, M.A.; Otranto, D. Keds, the enigmatic flies and their role as vectors of pathogens. Acta Trop. 2020, $209,105521$. [CrossRef] [PubMed]

5. Kowal, J.; Nosal, P.; Kornaś, S.; Wajdzik, M.; Matysek, M.; Basiaga, M. Biodiversity and importance of hippoboscids infection in cervids. Med. Weter. 2016, 72, 745-749.

6. Maa, T.C. A synopsis of the Lipopteninae. J. Med. Entomol. 1965, 2, 233-248. [CrossRef] [PubMed]

7. Borowiec, L.; Zatwarnicki, T. Lipoptena fortisetosa Maa, 1965 (Diptera, Hippoboscidae), nowy gatunek dla fauny Polski. Prz. Zool. 1989, 33, 579-582.

8. Kowal, J.; Nosal, P.; Rościszewska, M.; Matysek, M. New records of Lipoptena fortisetosa Maa, 1965 (Diptera:Hippoboscidae) in Poland. Dipteron 2009, 25, 27-29.

9. Cydzik, K.; Kadulski, S. Parasitic Insects of the Red Deer (Cervus elaphus L.) in Northeastern Poland. Stawonogi. Inwazje $i$ Ich Ograniczanie; Akapit: Lublin, Poland, 2009; pp. 113-115.

10. Jedrysik, D.; Kadulski, S. Parasitic Arthropods of Roe Deer Capreolus capreolus (L.) of the Region of Pojezierze Potudniowobattyckie (The Southern Baltic Lake District). Arthropods. The Medical and Economic Importance; Akapit: Lublin, Poland, 2012; pp. 95-103.

11. Matysek, M.; Kowal, J. Dwa nowe gatunki muchówek. Tatry 2014, 48, 64-65.

12. Kadulski, S. Lipoptena Nitzsch, 1818 in Poland. Wiadomości Parazytologiczne 1998, 44, 462.

13. Sokół, R.; Gałęcki, R. Prevalence of keds on city dogs in central Poland. Med. Vet. Entomol. 2017, 31, 114-116. [CrossRef] [PubMed]

14. Gałęcki, R.; Jaroszewski, J.; Xuan, X.; Bakuła, T. Temporal-Microclimatic Factors Affect the Phenology of Lipoptena fortisetosa in Central European Forests. Animals 2020, 10, 2012. [CrossRef] [PubMed]

15. Hermosilla, C.; Pantchev, N.; Bachmann, R.; Bauer, C. Lipoptena cervi (deer ked) in two naturally infested dogs. Vet. Rec. 2006, 159, 286. [CrossRef] [PubMed]

16. Kadulski, S. Ectoparasites of Cervidae in north-east Poland. Acta Parasitol. 1996, 41, $204-210$.

17. Szczurek, B.; Kadulski, S. Ectoparasites on fallow deer, Dama dama (L.) in Pomerania, Poland. Acta Parasitol. $2004,49,80-86$.

18. Izdebska, J.N. European bison arthropod parasites from closed Polish breeding facilities. Acta Parasitol. 2001, 46, $135-137$.

19. Metelitsa, A.K.; Veselkin, G.A. Parasitism of the louse fly Lipoptena fortisetosa on cattle. Parazitologiia 1989, 23, $276-277$.

20. Dehio, C.; Sauder, U.; Hiestand, R. Isolation of Bartonella schoenbuchensis from Lipoptena cervi, a blood-sucking arthropod causing deer ked dermatitis. J. Clin. Microbiol. 2004, 42, 5320-5323. [CrossRef]

21. Ivanov, V.I. Anthropophilia of the deer blood sucker Lipoptena cervi L. (Diptera, Hippoboscidae). Med. Parazitol. 1975, 44, 491-495.

22. Buczek, W.; Buczek, A.M.; Bartosik, K.; Buczek, A. Comparison of skin lesions caused by Ixodes ricinus ticks and Lipoptena cervi deer keds infesting humans in the natural environment. Int. J. Environ. Res. Public Health 2020, 17, 3316. [CrossRef]

23. Maślanko, W.; Bartosik, K.; Raszewska-Famielec, M.; Szwaj, E.; Asman, M. Exposure of Humans to Attacks by Deer Keds and Consequences of Their Bites-A Case Report with Environmental Background. Insects 2020, 11, 859. [CrossRef]

24. Vikøren, T.; Lillehaug, A.; Handeland, K. Helseovervakingsprogrammet for Hjortevilt (HOP), Årsrapport for 2006 og 2007 ; National Veterinary Inst. Report Series; National Veterinary Institute: Oslo, Norway, 2008.

25. Madslien, K.; Ytrehus, B.; Vikøren, T.; Malmsten, J.; Isaksen, K.; Hygen, H.O.; Solberg, E.J. Hair-loss epizootic in moose (Alces alces) associated with massive deer ked (Lipoptena cervi) infestation. J. Wildl. Dis. 2011, 47, 893-906. [CrossRef]

26. Rantanen, T.; Reunala, T.; Vuojolahti, P.; Hackman, W. Persistent pruritic papules from deer ked bites. Acta Derm. Venereol. 1982, $62,307-311$.

27. Laukkanen, A.; Ruoppi, P.; Mäkinen-Kiljunen, S. Deer ked-induced occupational allergic rhinoconjunctivitis. Ann. Allergy Asthma Immunol. 2005, 94, 604-608. [CrossRef]

28. Decastello, A.; Farkas, R. Anaphylactic reaction following forest fly (Hippobosca equina) bite: A human case. Clin. Exp. Med J. 2010, 4, 193-198. [CrossRef]

29. Benelli, G.; Duggan, M.F. Management of arthropod vector data-Social and ecological dynamics facing the One Health perspective. Acta Trop. 2018, 182, 80-91. [CrossRef]

30. Mencke, N. Future challenges for parasitology: Vector control and 'One health'in Europe: The veterinary medicinal view on CVBDs such as tick borreliosis, rickettsiosis and canine leishmaniosis. Vet. Parasitol. 2013, 195, 256-271. [CrossRef]

31. Baker, J.R. A review of the role played by the Hippoboscidae (Diptera) as vectors of endoparasites. J. Parasitol. 1967, 53, 412-418. [CrossRef]

32. Regier, Y.; Komma, K.; Weigel, M.; Pulliainen, A.T.; Göttig, S.; Hain, T.; Kempf, V.A. Microbiome analysis reveals the presence of Bartonella spp. and Acinetobacter spp. in deer keds (Lipoptena cervi). Front. Microbiol. 2018, 9, 3100. [CrossRef]

33. Lee, S.H.; Kim, K.T.; Kwon, O.D.; Ock, Y.; Kim, T.; Choi, D.; Kwak, D. Novel detection of Coxiella spp.; Theileria luwenshuni, and T. ovis endosymbionts in deer keds (Lipoptena fortisetosa). PLoS ONE 2016, 11, e0156727. 
34. Böse, R.; Petersen, K. Lipoptena cervi (Diptera), a potential vector of Megatrypanum trypanosomes of deer (Cervidae). Parasitol. Res. 1991, 77, 723-725. [CrossRef]

35. Werszko, J.; Steiner-Bogdaszewska, Ż.; Jeżewski, W.; Szewczyk, T.; Kuryło, G.; Wołkowycki, M.; Wróblewski, P.; Karbowiak, G. Molecular detection of Trypanosoma spp. in Lipoptena cervi and Lipoptena fortisetosa (Diptera: Hippoboscidae) and their potential role in the transmission of pathogens. Parasitology 2020, 147, 1-7. [CrossRef]

36. Hornok, S.; de la Fuente, J.; Biró, N.; Fernández de Mera, I.G.; Meli, M.L.; Elek, V.; Gönczi, E.; Meili, T.; Tánczos, B.; Farkas, R.; et al. First molecular evidence of Anaplasma ovis and Rickettsia spp. in keds (Diptera: Hippoboscidae) of sheep and wild ruminants. Vector Borne Zoonotic Dis. 2011, 11, 1319-1321. [CrossRef]

37. Víchová, B.; Majláthová, V.; Nováková, M.; Majláth, I.; Čurlík, J.; Bona, M.; Komjáti-Nagyová, M.; Pet'ko, B. PCR detection of re-emerging tick-borne pathogen, Anaplasma phagocytophilum, in deer ked (Lipoptena cervi) a blood-sucking ectoparasite of cervids. Biologia 2011, 66, 1082. [CrossRef]

38. Doby, J.M.; Bigaignon, G.; Degeilh, B.; Guiguen, C. Ectoparasites of large wild mammals (deer and wild boars) and Lyme borreliosis. Search for Borrelia burgdorferi in more than 1400 ticks, lice, Pupipara Diptera and fleas. Rev. Med. Vet-Toulouse 1994, $145,743-748$.

39. Hulinsky, V.; Smetana, K. Molecular and microscopical evidence of Ehrlichia spp. and Borrelia burgdorferi sensu lato in patients, animals and ticks in the Czech Republic. New Microbiol. 2002, 25, 437-448.

40. De Bruin, A.; Van Leeuwen, A.D.; Jahfari, S.; Takken, W.; Földvári, M.; Dremmel, L.; Sprong, H.; Földvári, G. Vertical transmission of Bartonella schoenbuchensis in Lipoptena cervi. Parasites Vectors 2015, 8, 176. [CrossRef]

41. Korhonen, E.M.; Vera, C.P.; Pulliainen, A.T.; Sironen, T.; Aaltonen, K.; Kortet, R.; Härkönen, L.; Härkönen, S.; Paakkonen, T.; Nieminen, P.; et al. Molecular detection of Bartonella spp. in deer ked pupae, adult keds and moose blood in Finland. Epidemiol. Infect. 2015, 143, 578-585. [CrossRef]

42. Songailaitè, L.; Klepeckienè, K.; Paulauskas, A.; Radzijevskaja, J. Molecular detection of Bartonella spp. in deer keds Lipoptena cervi and Lipoptena fortisetosa in Lithuania. In Proceedings of the Smart Bio: ICSB 2nd International Conference, Kaunas, Lithuania, 3-5 May 2018; Abstracts book. Vytautas Magnus University: Kaunas, Lithuania, 2018.

43. Szewczyk, T.; Werszko, J.; Steiner-Bogdaszewska, Ż.; Jeżewski, W.; Laskowski, Z.; Karbowiak, G. Molecular detection of Bartonella spp. in deer ked (Lipoptena cervi) in Poland. Parasites Vectors 2017, 10, 487. [CrossRef]

44. Andreani, A.; Sacchetti, P.; Belcari, A. Comparative morphology of the deer ked Lipoptena fortisetosa first recorded from Italy. Med. Vet. Entomol. 2019, 33, 140-153. [CrossRef]

45. Kurina, O.; Kirik, H.; Ounap, H.; Õunap, E. The northernmost record of a blood-sucking ectoparasite, Lipoptena fortisetosa Maa (Diptera: Hippoboscidae), in Estonia. Biodivers. Data J. 2019, 7, e47857. [CrossRef]

46. Paakkonen, T. Ecophysiology of the Deer Ked (Lipoptena cervi) and Its Hosts. Ph.D. Thesis, University of Eastern Finland, Joensuu, Finland, 2012. Available online: https:/ / core.ac.uk/download/pdf/15169155.pdf (accessed on 23 April 2020).

47. Härkönen, S.; Laine, M.; Vornanen, M.; Reunala, T. Deer ked (Lipoptena cervi) dermatitis in humans-an increasing nuisance in Finland. Alces 2009, 45, 73-79.

48. Kortet, R.; Härkönen, L.; Hokkanen, P.; Härkönen, S.; Kaitala, A.; Kaunisto, S.; Laaksonen, S.; Kekäläinen, J.; Ylönen, H. Experiments on the ectoparasitic deer ked that often attacks humans; preferences for body parts, colour and temperature. Bull. Entomol. Res. 2010, 100, 279. [CrossRef]

49. Halkman, W. Immigration of Lipoptera cervi (Diptera, Hippoboscidae) in Finland, with notes on its biology and medical significance. Not. Entomol. 1983, 63, 53-59.

50. Davis, J.W. Deer ked infestation on white-tailed deer in East Texas. J Wildl. Manag. 1973, 37, 183-186. [CrossRef]

51. Samuel, W.; Trainer, D. Lipoptena mazamae Rondani, 1878 (Diptera: Hippoboscidae) on white-tailed deer in southern Texas. J. Med. Entomol. 1972, 9, 104-106. [CrossRef] [PubMed]

52. Frischknecht, F. The skin as interface in the transmission of arthropod-borne pathogens. Cell. Microbiol. 2007, 9, 1630-1640. [CrossRef] [PubMed]

53. Jaenson, T.G.; Tälleklint, L. Incompetence of roe deer as reservoirs of the Lyme borreliosis spirochete. J. Med. Entomol. 1992, 29, 813-817. [CrossRef] [PubMed]

54. Haarløv, N. Life cycle and distribution pattern of Lipoptena cervi (L.) (Dipt.; Hippobosc.) on Danish deer. Oikos 1964, 15, 93-129. [CrossRef]

55. Barns, S.M.; Grow, C.C.; Okinaka, R.T.; Keim, P.; Kuske, C.R. Detection of diverse new Francisella-like bacteria in environmental samples. Appl. Environ. Microbiol. 2005, 71, 5494-5500. [CrossRef]

56. Shabbir, M.Z.; Akram, S.; ul Hassan, Z.; Hanif, K.; Rabbani, M.; Muhammad, J.; Chaudhary, M.H.; Abbas, T.; Ghori, M.T.; Rashid, H.; et al. Evidence of Coxiella burnetii in Punjab province, Pakistan. Acta Trop. 2016, 163, 61-69. [CrossRef]

57. Watanabe, Y.; Fujihara, M.; Obara, H.; Matsubara, K.; Yamauchi, K.; Harasawa, R. Novel hemoplasma species detected in free-ranging sika deer (Cervus nippon). J. Vet. Med. Sci. 2010, 72, 1527-1530. [CrossRef] [PubMed]

58. Evans, A.S. Causation and disease: The Henle-Koch postulates revisited. Yale J. Biol. Med. 1976, $49,175$.

59. Gradmann, C. A spirit of scientific rigour: Koch's postulates in twentieth-century medicine. Microbes Infect. 2014, 16, 885-892. [CrossRef] [PubMed]

60. Byrd, A.L.; Segre, J.A. Adapting Koch's postulates. Science 2016, 351, 224-226. [CrossRef] [PubMed]

61. Gray, J.S.; Estrada-Peña, A.; Zintl, A. Vectors of babesiosis. Annu. Rev. Entomol. 2019, 64, 149-165. [CrossRef] [PubMed] 
62. Buss, M.; Case, L.; Kearney, B.; Coleman, C.; Henning, J.D. Detection of Lyme disease and anaplasmosis pathogens via PCR in Pennsylvania deer ked. J. Vector Ecol. 2016, 41, 292-294. [CrossRef]

63. Hornok, S.; Takács, N.; Szekeres, S.; Szőke, K.; Kontschán, J.; Horváth, G.; Sugár, L. DNA of Theileria orientalis, T. equi and T. capreoli in stable flies (Stomoxys calcitrans). Parasites Vectors 2020,13, 1-6. [CrossRef]

64. Yanovski, A.D.; Ogston, C.W. Sex differences in size of the blood meal in the bed bug Cimex hemipterus (Hemiptera: Cimicidae). J. Med. Entomol. 1982, 19, 45-47. [CrossRef]

65. Lehane, M. The Biology of Blood-Sucking in Insects; Cambridge University Press: Cambridge, UK, 2005; pp. $202-258$.

66. Mustonen, A.M.; Käkelä, R.; Paakkonen, T.; Nieminen, P. Life stage-related differences in fatty acid composition of an obligate ectoparasite, the deer ked (Lipoptena cervi)—Influence of blood meals and gender. CBP Part A Mol. Integr. Physiol. 2015, 179, 62-70. [CrossRef]

67. Kauffmann, M.; Rehbein, S.; Hamel, D.; Lutz, W.; Heddergott, M.; Pfister, K.; Silaghi, C. Anaplasma phagocytophilum and Babesia spp. in roe deer (Capreolus capreolus), fallow deer (Dama dama) and mouflon (Ovis musimon) in Germany. Mol. Cell. Probes 2017, 31, 46-54. [CrossRef] [PubMed]

68. Sawczuk, M.; Maciejewska, A.; Skotarczak, B. Identification and molecular characterization of Theileria sp. infecting red deer (Cervus elaphus) in northwestern Poland. Eur. J. Wildl. Res. 2008, 54, 225-230. [CrossRef]

69. Bruno, P.; Bruno, G.; Claudine, P.E. Detection of spirochaetes of Borrelia burgdorferi complexe in the skin of cervids by PCR and culture. Eur. J. Epidemiol. 2000, 16, 869-873. [CrossRef]

70. Sacristán, C.; das Neves, C.G.; Suhel, F.; Sacristán, I.; Tengs, T.; Hamnes, I.S.; Madslien, K. Bartonella spp. detection in ticks, Culicoides biting midges and wild cervids from Norway. Transbound. Emerg. Dis. 2020, 1-11. [CrossRef] [PubMed]

71. Dehio, C.; Lanz, C.; Pohl, R.; Behrens, P.; Bermond, D.; Piémont, Y.; Pelz, K.; Sander, A. Bartonella schoenbuchii sp. nov.; isolated from the blood of wild roe deer. Int. J. Syst. Evol. Microbiol. 2001, 51, 1557-1565. [CrossRef] [PubMed]

72. Astobiza, I.; Barral, M.; Ruiz-Fons, F.; Barandika, J.F.; Gerrikagoitia, X.; Hurtado, A.; García-Pérez, A.L. Molecular investigation of the occurrence of Coxiella burnetii in wildlife and ticks in an endemic area. Vet. Microbiol. 2011, 147, 190-194. [CrossRef] [PubMed]

73. Oaaland, T.; Christiansen, E.; Jonsson, B.; Kapperud, G.; Wiger, R. A survey of tularemia in wild mammals from Fennoscandia. J. Wildl. Dis. 1977, 13, 393-399. [CrossRef]

74. Bourque, M.; Higgins, R. Serologic studies on brucellosis, leptospirosis and tularemia in moose (Alces alces) in Quebec. J. Wildl. Dis. 1984, 20, 95-99. [CrossRef] [PubMed]

75. Aguirre, A.A.; Hansen, D.E.; Starkey, E.E.; McLean, R.G. Serologic survey of wild cervids for potential disease agents in selected national parks in the United States. Prev. Vet. Med. 1995, 21, 313-322. [CrossRef]

76. Grazziotin, A.L.; Santos, A.P.; Guimaraes, A.M.S.; Mohamed, A.; Cubas, Z.S.; de Oliveira, M.J.; dos Santos, L.C.; de Moraes, W.; da Costa Vieira, R.F.; Donatti, L.; et al. Mycoplasma ovis in captive cervids: Prevalence, molecular characterization and phylogeny. Vet. Microbiol. 2011, 152, 415-419. [CrossRef] [PubMed]

77. Grazziotin, A.L.; Duarte, J.M.B.; Szabó, M.P.J.; Santos, A.P.; Guimarães, A.M.S.; Mohamed, A.; da Costa Vieira, R.F.; de Barros Filho, I.R.; Biondo, A.W.; Messick, J.B. Prevalence and molecular characterization of Mycoplasma ovis in selected free-ranging Brazilian deer populations. J. Wildl. Dis. 2011, 47, 1005-1011. [CrossRef]

78. Stefanidesova, K.; Kocianova, E.; Boldis, V.; Kostanova, Z.; Kanka, P.; Nemethova, D.; Spitalska, E. Evidence of Anaplasma phagocytophilum and Rickettsia helvetica infection in free-ranging ungulates in central Slovakia. Eur. J. Wildl. Res. 2008, 54, 519-524. [CrossRef]

79. Inokuma, H.; Seino, N.; Suzuki, M.; Kaji, K.; Takahashi, H.; Igota, H.; Inoue, S. Detection of Rickettsia helvetica DNA from peripheral blood of sika deer (Cervus nippon yesoensis) in Japan. J. Wildl. Dis. 2008, 44, 164-167. [CrossRef]

80. Elfving, K.; Malmsten, J.; Dalin, A.M.; Nilsson, K. Serologic and molecular prevalence of Rickettsia helvetica and Anaplasma phagocytophilum in wild cervids and domestic mammals in the central parts of Sweden. Vector Borne Zoonotic Dis. 2015, 15, 529-534. [CrossRef]

81. Ochirkhuu, N.; Konnai, S.; Odbileg, R.; Murata, S.; Ohashi, K. Molecular epidemiological survey and genetic characterization of Anaplasma species in Mongolian livestock. Vector Borne Zoonotic Dis. 2017, 17, 539-549. [CrossRef] [PubMed]

82. Bown, K.J.; Lambin, X.; Ogden, N.H.; Petrovec, M.; Shaw, S.E.; Woldehiwet, Z.; Birtles, R.J. High-resolution genetic fingerprinting of European strains of Anaplasma phagocytophilum by use of multilocus variable-number tandem-repeat analysis. J. Clin. Microbiol. 2007, 45, 1771-1776. [CrossRef]

83. Hilpertshauser, H.; Deplazes, P.; Schnyder, M.; Gern, L.; Mathis, A. Babesia spp. identified by PCR in ticks collected from domestic and wild ruminants in southern Switzerland. Appl. Environ. Microbiol. 2006, 72, 6503-6507. [CrossRef] [PubMed]

84. Jensen, W.A.; Fall, M.Z.; Rooney, J.; Kordick, D.L.; Breitschwerdt, E.B. Rapid Identification and Differentiation of Bartonella Species Using a Single-Step PCR Assay. J. Clin. Microbiol. 2000, 38, 1717-1722. [CrossRef]

85. Barbour, A.G.; Maupin, G.O.; Teltow, G.J.; Carter, C.J.; Piesman, J. Identification of an uncultivable Borrelia species in the hard tick Amblyomma americanum: Possible agent of a Lyme disease-like illness. J. Infect. Dis. 1996, 173, 403-409. [CrossRef]

86. Zheng, W.; Liu, M.; Moumouni, P.F.A.; Liu, X.; Efstratiou, A.; Liu, Z.; Liu, Y.; Tao, H.; Guo, H.; Wang, G.; et al. First molecular detection of tick-borne pathogens in dogs from Jiangxi, China. J. Vet. Sci. 2017, 79, 248-254. [CrossRef]

87. Long, G.W.; Oprandy, J.J.; Narayanan, R.B.; Fortier, A.H.; Porter, K.R.; Nacy, C.A. Detection of Francisella tularensis in blood by polymerase chain reaction. J. Clin. Microbiol. 1993, 31, 152-154. [CrossRef] [PubMed] 
88. Liu, M.; Ruttayaporn, N.; Saechan, V.; Jirapattharasate, C.; Vudriko, P.; Moumouni, P.F.A.; Cao, S.; Inpankaew, T.; Ybañez, A.P.; Suzuki, H.; et al. Molecular survey of canine vector-borne diseases in stray dogs in Thailand. Parasitol. Int. 2016, 65, 357-361. [CrossRef]

89. Labruna, M.B.; Whitworth, T.; Horta, M.C.; Bouyer, D.H.; McBride, J.W.; Pinter, A.; Popov, V.; Gennari, S.M.; Walker, D.H Rickettsia species infecting Amblyomma cooperi ticks from an area in the state of Sao Paulo, Brazil, where Brazilian spotted fever is endemic. J. Clin. Microbiol. 2004, 42, 90-98. [CrossRef] [PubMed]

90. Li, Y.; Chen, Z.; Liu, Z.; Liu, J.; Yang, J.; Li, Q.; Li, Y.; Cen, S.; Guan, G.; Ren, Q.; et al. Molecular identification of Theileria parasites of northwestern Chinese Cervidae. Parasites Vectors 2014, 7, 1-7. [CrossRef]

91. Hall, T.A. BioEdit: A user-friendly biological sequence alignment editor and analysis program for Windows 95/98/NT. Nucleic Acids Symp. Ser. 1999, 41, 95-98.

92. Molecular Evolutionary Genetics Analysis. Available online: https://www.megasoftware.net (accessed on 3 September 2019). 